\title{
Development of Learning Model Based on Cognitive Processes in Mathematical Investigation
}

\author{
Sri Subarinah* \\ Mathematics Education Study Program \\ University of Mataram \\ Mataram, Indonesia \\ srisubarinah.fkip@unram.ac.id
}

\author{
Nyoman Sridana \\ Mathematics Education Study Program \\ University of Mataram \\ Mataram, Indonesia \\ sridana60@gmail.com
}

\author{
Sudi Prayitno \\ Mathematics Education Study Program \\ University of Mataram \\ Mataram, Indonesia \\ s.prayitno@unram.ac.id
}

\begin{abstract}
A mathematical investigation is a scientific thinking activity that needs to be developed in learning. This study aims to construct a learning model based on the cognitive process of mathematical investigation (CPMI). Activities in the mathematical investigation have 4 stages of cognitive processes, namely specializing, conjecturing, justifying, and generalizing. Model construction includes the preparation of the model book, learning syntax, and lesson plans. This model has a learning syntax which is divided into six stages, namely (1) introducing of mathematical investigation task, (2) trying special cases individually (specializing), (3) work in a group to make conjectures, justification, and generalization, (4) presenting the group discussion results, (5) reviews, and (6) conclusions and follow-up. The constructed model was validated by 5 mathematics education experts. The validation results concluded that the CPMI learning model is valid with minor revision. The advantage of the CPMI learning model is that it creates an academic activity that supports the improvement of students' problem-solving abilities.
\end{abstract}

Keywords—learning model, cognitive processes, mathematical investigation.

\section{INTRODUCTION}

A mathematical investigation is one of the activities required in learning mathematics [1], it can encourage activity to experiment, collect data, make observations, identify a pattern, make and test conclusions or conjectures and make a generalization [2]. This research strives for a mathematical learning model that explores cognitive processes in a mathematical investigation, it was an implementation of the results of previous studies [3].

The development of a learning model based on the cognitive process of mathematical investigation (CPMI) is one way to improve mathematics learning quality. If the quality of learning mathematics can be improved, some classical problems related to mathematics learning outcomes can be solved. For example the problem of Indonesian students who are weak in all aspects of content and cognitive when solving PISA problems. Indonesian students can solve (above $80 \%$ ) questions that are routine problems, simple computation, and measure knowledge of facts with daily contexts.
However, Indonesian students do not have (less than $11 \%$ ) the ability to integrate information, draw conclusions, and generalize their knowledge into other things [4]. These results indicate that mathematics learning in Indonesia still focuses on routine problems with simple mathematical computations, while mathematical investigation activities that require students to collecting some information, connecting the information, making and testing hypothesis, making conclusions and generalizations has not been implemented optimally.

Improvements in learning need to be pursued continuously by taking into account the latest education trends. Setiawan [5] presents several current trends in education, one of which is the transition from the theory of transfer of knowledge to interacting, investigating, exploration, open-ended activities, processing skills, modeling, and problem-solving. Mathematical investigation activity is a miniature activity of the scientific method presented in a scientific approach which includes (1) observing, (2) questioning, (3) experimenting, (4) associating, and (5) communicating [6].

The investigation process is needed in studying mathematics. The research of Calleja [7] showed that the investigation process has benefits for students in learning mathematics. This occurs because students work with investigations in a cooperative learning environment. Mathematical investigations make students comfortable in developing curiosity, dare to ask questions and express opinions, and dare to take risks and be confident, so that they are more active in thinking and can spark ideas in finding problems, especially those related to mathematics. While the results of Japa's [8] research indicate that the application of mathematical investigations can increase student activity, creativity, and productivity of thinking, as well as improve students' ability in solving open mathematics problems.

According to Yeo \& Yeab [9] the cognitive process in the mathematical investigation is the process of mental activity in a person's mind in attacking problems. The cognitive processes of the mathematical investigation were characterized using four terms of core cognitive processes, namely: (1) specializing, (2) conjecturing, (3) justifying, and (4) generalizing. Subarinah [10] was described indicators of the four cognitive processes are presented in Table I. 
TABLE I. INDICATORS OF COGNITIVE PROCESSES IN MATHEMATICAL INVESTIGATION

\begin{tabular}{|l|l|}
\hline $\begin{array}{l}\text { Cognitive } \\
\text { Processes }\end{array}$ & Indicators \\
\hline Specializing & $\begin{array}{l}\text { S1: Checking specific examples } \\
\text { S2: Trying some special cases }\end{array}$ \\
& $\begin{array}{l}\text { S3: Creating an image } \\
\text { S4: Taking important notes } \\
\text { S5: Simplifying assumptions } \\
\text { S6: Creating a systematic list to examine specific cases }\end{array}$ \\
\hline Conjecturing & C1: Creating and or changing estimates \\
& C2: Developing a coding system \\
& C3: Formulating a hypothesis \\
& C4: Attempting a related problem \\
& C5: Focusing attention to only one aspect of the \\
& problem \\
\hline Justifying & J1: Using one part of the solution to complete the other \\
& part \\
& J2: Eliminating irrelevant pathways of problem-solving \\
& J3: Using representations \\
& J4: Using inductive reasoning \\
\hline Generalizing & G1: Making a general formulation \\
& G2: Changing the representation, if necessary \\
& G3: Testing the general pattern for the special cases it \\
& has worked on
\end{tabular}

Yeo \& Yeap [9] and Subarinah [10] were made problemsolving model interacting with cognitive processes. Stage of this model were: (1) Entry (understanding task), (2) Attack (interaction of specialization, conjecturing, justifying, and generalization or using another heuristic), (3) review (from generalization), and (4) extension. Putri [11] and Anggraini et al. [12] applying a group investigation model with six stages arranged, which are grouping, planning, investigation, organizing, presenting, and evaluating. Sharan \& Sharan [13] argue that in this model students are not required to find problems, but are more required to solve problems. Muhandas [14] prioritizes discovery as a form of a group investigation. The application of the group investigative learning model can generate thinking and conceptual change challenges. Also, if students have advanced group investigation skills, they have the skills to elaborate a concept which results in a deeper understanding and higher problem-solving abilities which in turn fosters positive motivation and better attitudes.

\section{METHOD}

This research is the initial part of developing a mathematics learning model based on cognitive processes in mathematical investigations. The learning model that is prepared contains a model book, syntax, and examples of learning plans. This initial study was in the form of validation of the learning model, namely content validation by five mathematics education experts. This validity refers to the accuracy of measurement based on the content of the instrument to ensure that the scale items used have met the overall content of the concept or the suitability of the items.

The content validity in this study was measured using the Aiken formula. Aiken (in [15]) formulated Aiken's V formula to calculate the content-validity coefficient which is based on the results of the assessment of $\mathrm{n}$ expert validators on an item in terms of the extent to which the item represents the construct being measured. The formula proposed by Aiken is as follows.

$$
V=\sum \frac{r_{i}-l_{0}}{n(c-1)}
$$

Where, $l_{0}=$ lowest scorer of validity assessments; $c=$ highest score of validity assessments; $n=$ number of validators; and $r_{\mathrm{i}}=$ score given by the appraiser/validators, where $i=1,2,3, \ldots, n$.

\section{RESULTS AND DISCUSSION}

The mathematics learning model based on cognitive processes in mathematical investigations (CPMI) proposed in this study has the following syntax:

1) Introducing of mathematical investigation task

2) Trying special cases individually (specializing)

3) Work in a group to make conjectures, justification, and generalization

4) Presenting the group discussion results

5) Reviews

6) Conclusions and follow-up.

Based on the syntax of the CPMI learning model, a model book and learning tools were prepared. The model book describes the literature study, this learning model is developed to obtain learning syntax and its descriptions. Meanwhile, the learning tools arranged are examples of mathematics learning for junior high school students who apply the CPMI based learning model. In the device, a closed and open problem student worksheet is attached.

Model books, learning syntax, and learning tools that have been compiled are sent for an assessment with a rating scale of 1 to 5. The questions asked can be grouped as follows:

1) Readability of model books (language, construction, references, links between concepts that appear in the formulation of the model, novelty).

2) Rational of syntax CPMI-based learning model (sequence, linkage, completeness of elements, language, construction, compatibility with the essence of mathematics).

3) Learning plans (completeness, difficulty level of assignments, readability of assignments, compliance with the curriculum, student activities, teacher activities, time management, practicality, evaluation, worksheets, and, student/teacher reference materials).

Based on this grouping, seventeen statements were put forward with scores of (1) strongly disagree, (2) disagree, (3) doubt, (4) agree, and (5) strongly agree. These statements are presented in Table II.

TABLE II. LIST OF STATEMENTS GIVEN THE ASSESSMENT

\begin{tabular}{|c|c|}
\hline No & Assessed Statement \\
\hline & Assessment of model books \\
\hline 1. & $\begin{array}{l}\text { Presenting the contents of the book in easy to understand } \\
\text { language }\end{array}$ \\
\hline 2. & $\begin{array}{l}\text { The structure of the book is presented in order, coherent, and } \\
\text { logical }\end{array}$ \\
\hline 3. & $\begin{array}{l}\text { The model book is prepared using adequate references, from } \\
\text { basic/initial to current references }\end{array}$ \\
\hline 4. & $\begin{array}{l}\text { The model book presents the relationship between concepts } \\
\text { in compiling CPMI-based learning syntax }\end{array}$ \\
\hline \multirow[t]{2}{*}{5.} & The compiled model has elements of novelty and originality \\
\hline & Assessment of the CPMI-based learning model syntax \\
\hline 6. & $\begin{array}{l}\text { The language of conveying learning syntax meets the rules } \\
\text { of the General Guidelines for Indonesian Spelling (PUEBI) } \\
\text { which are good and correct }\end{array}$ \\
\hline 7. & $\begin{array}{l}\text { The syntactic sequence of the learning model fulfills a } \\
\text { logical, educational, and characteristic learning sequence }\end{array}$ \\
\hline
\end{tabular}




\begin{tabular}{|r|l|}
\hline 8. & $\begin{array}{l}\text { The elements of the learning model syntax are interrelated to } \\
\text { support the implementation of complete learning }\end{array}$ \\
\hline 9. & $\begin{array}{l}\text { The elements of the learning model syntax fulfill the } \\
\text { elements of completeness in learning }\end{array}$ \\
\hline 10. & $\begin{array}{l}\text { The syntax of the CPMI-based learning model can be } \\
\text { implemented in mathematics learning, which is abstract } \\
\text { knowledge and problem solving }\end{array}$ \\
\hline 11. & $\begin{array}{l}\text { The syntax for the CPMI-based learning model is } \\
\text { constructed based on cognitive processes when students } \\
\text { learn actively }\end{array}$ \\
\hline 12. & $\begin{array}{l}\text { Assessment of learning tools (lesson plans, worksheets, } \\
\text { evaluation) }\end{array}$ \\
\hline 13. & $\begin{array}{l}\text { A complete lesson plan is prepared (detailed steps, student } \\
\text { worksheets available, evaluation available) }\end{array}$ \\
\hline 14. & $\begin{array}{l}\text { The lesson plan is prepared based on the CPMI learning } \\
\text { the time for } \text { learning stevised curriculum step }\end{array}$ \\
\hline 15. & $\begin{array}{l}\text { The task of investigating mathematics has a difficulty level } \\
\text { according to the cognitive development of junior high } \\
\text { school students }\end{array}$ \\
\hline 16. & $\begin{array}{l}\text { Mathematical investigation tasks are arranged in a language } \\
\text { that is easy for students to understand }\end{array}$ \\
\hline 17. & $\begin{array}{l}\text { The lesson plan prepared allows it to be applied in junior } \\
\text { high school mathematics learning }\end{array}$ \\
\hline
\end{tabular}

Based on the results of the evaluation of the five validators, it was concluded that there was a similarity in the views of the validators, which was indicated by the Aiken $V$ number for each item which was more than 0.75 , which shows that the content validity was accepted. However, several items need to be repaired, especially in learning tools. Also, the average score for all aspects is 4.72 out of a maximum score of 5 . This illustrates that the model developed was assessed by the validator in the very good category. After correcting it, a valid CPMI-based learning model is obtained and ready to be implemented. However, the Covid-19 pandemic situation has not subsided so that junior high schools in Mataram city have not conducted face-to-face learning, so the implementation of this learning model is waiting for the pandemic situation to improve.

\section{CONCLUSION}

A valid mathematical investigative cognitive processbased learning model has been successfully developed. This model has a learning syntax which is divided into six stages, namely (1) Introducing of mathematical investigation task, (2) Trying special cases individually (specializing), (3) Work in a group to make conjectures, justification, and generalization, (4) Presenting the group discussion results, (5) Reviews, and (6) Conclusions and follow-up.

\section{ACKNOWLEDGMENT}

Thank you for the PNBP funding support from DIPA BLU University of Mataram for the 2020 fiscal year with the agreement contract number: 2641/UN18.L1/PP/2020.

\section{REFERENCES}

[1] L. Grimison and L. Dawe L, Literature review: report on investigational tasks in mathematics in years 9-10 for advanced and intermediate students. New South Wales: University of New South Wales, 2000.

[2] B. H. Bastow, J. Kissane, and R. Randall, Another 20 mathematical investigational work. Pert: The Mathematical Association of Western Australia (MAWA), 1984

[3] S. Subarinah, K. Budayasa, A and Lukito, "Profile of Junior High School Student in Mathematical Investigation," Jurnal Ilmiah Profesi Pendidikan, vol. 3, no. 1, pp. 15-23, 2018.

[4] R. Rahmawati, Result of TIMSS 2015: Diagnosis of results for quality improvement and performance improvement. Paper presented at the seminar on educational assessment results for policy on December 14, 2016. Jakarta: Education Assessment Center, Research and Development Agency, Ministry of Education and Culture, 2016.

[5] S. Setiawan, Mathematics learning model with an investigative approach.Yogyakarta : P3G Matematika, 2006

[6] R. Roheni, T. Herman, and A. Jupri, "Scientific approach to improve mathematical problem solving skills student of grade V," Journal of Physics: Conf. Series, vol. 895, 2017.

[7] J. Calleja, Integrating investigations in secondary school mathematics (Dissertation). Malta: University of Malta, 2011.

[8] I. G. N. Japa, "Improving open mathematics problem solving skills through investigations for grade V students of SD 4 Kaliuntu," Jurnal Penelitian dan Pengembangan Pendidikan, vol. 2, no. 1, pp. 60-73, 2008 .

[9] J. B. W. Yeo and B. H Yeap, "Characterising the cognitive processes in mathematical investigation. Journal for Mathematics Teaching and Learning," pp. 1-10, 2010.

[10] S. Subarinah, The profile of the cognitive processes of junior high school students in mathematical investigations in terms of differences in mathematical abilities and gender (Dissertation). Surabaya: PPS Universitas Negeri Surabaya, 2017.

[11] Y. B. Putri, 2016. Group Investigation Learning Model and Student Problem Solving Ability in Mathematics Learning," PRISMA, Proceeding of Mathematics National Seminar, pp. 44-49, 2016.

[12] L. Anggraini, R. A. Siroj and R. I. I. Putri, "Application of Group Investigation Learning Model to Improve Mathematics Problem Solving Ability of Class VIII-4 Students of SMP 27 Palembang," Jurnal Pendidikan Matematika, vol. 4, no. 1, pp. 33-45, 2010.

[13] Y. Sharan and S. Sharan, "Group Investigation Expands Cooperative Learning,” Educational Leadership Journal, pp. 17-21, 1990.

[14] R. Muhandas, "The Effect of Cooperative Learning Model Group Investigation Type on Mathematical Problem Solving Class VIII Students of MTsN Padang," Suska Journal of Mathematics Education, vol. 1, no. 1, pp. 35-44, 2015.

[15] S. Azwar, Reliability and Validity. Issue 4. Yogyakarta: Pustaka Pelajar, 2012. 